\title{
Keeping people with epilepsy safe during the COVID-19 pandemic
}

Jacqueline A. French, MD, Martin J. Brodie, MD, Roberto Caraballo, MD, Orrin Devinsky, MD, Ding Ding, MPH, PhD, Lara Jehi, MD, Nathalie Jette, MSc, MD, Andres Kanner, MD, Avani C. Modi, PhD, Charles R. Newton, MD, FRCP, Archana A. Patel, MD, MPH, Page B. Pennell, MD, Emilio Perucca, MD, PhD, Josemir W. Sander, MD, PhD, FRCP, Ingrid E. Scheffer, MBBS, PhD, Gagandeep Singh, MD, Emma Williams, Jo Wilmshurst, MBBS, MD, and J. Helen Cross, MBChB, PhD

Neurolog ${ }^{\circledR}$ 2020;94:1032-1037. doi:10.1212/WNL.0000000000009632

\section{Abstract}

\section{Objectives}

To provide information on the effect of the coronavirus disease of 2019 (COVID-19) pandemic on people with epilepsy and provide consensus recommendations on how to provide the best possible care for people with epilepsy while avoiding visits to urgent care facilities and hospitalizations during the novel coronavirus pandemic.

\section{Methods}

The authors developed consensus statements in 2 sections. The first was "How should we/ clinicians modify our clinical care pathway for people with epilepsy during the COVID-19 pandemic?" The second was "What general advice should we give to people with epilepsy during this crisis? The authors individually scored statements on a scale of -10 (strongly disagree) to +10 (strongly agree). Five of 11 recommendations for physicians and 3/5 recommendations for individuals/families were rated by all the authors as 7 or above (strongly agree) on the first round of rating. Subsequently, a teleconference was held where statements for which there was a lack of strong consensus were revised.

\section{Results}

After revision, all consensus recommendations received a score of 7 or above. The recommendations focus on administration of as much care as possible at home to keep people with epilepsy out of health care facilities, where they are likely to encounter COVID-19 (including strategies for rescue therapy), as well as minimization of risk of seizure exacerbation through adherence, and through ensuring a regular supply of medication. We also provide helpful links to additional helpful information for people with epilepsy and health providers.

\section{Conclusion}

These recommendations may help health care professionals provide optimal care to people with epilepsy during the coronavirus pandemic.

\author{
Correspondence \\ Dr. French \\ Jacqueline.french@ \\ nyulangone.org
}

MORE ONLINE

\section{COVID-19 Resources}

For the latest articles, invited commentaries, and blogs from physicians around the world

NPub.org/COVID 19

\footnotetext{
From the Department Neurology (J.A.F.), NYU Grossman School of Medicine New York University, NY; Epilepsy Unit (M.J.B.), International Bureau for Epilepsy, Scottish Epilepsy Initiative, Glasgow, Scotland; Neurology (R.C.), Hospital J P Garrahan, Buenos Aires, AR; Department Neurology (O.D.), NYU Grossman School of Medicine, NY; Institute of Neurology (D.D.), Huashan Hospital, Fudan University, Shanghai, China; Cleveland Clinic Epilepsy Center (L.J.), Cleveland, OH; Department of Neurology (N.J.), Icahn School of Medicine at Mount Sinai, New York, NY; Division of Epilepsy (A.K.), Department of Neurology, Miller School of Medicine, University of Miami, FL; Cincinnati Children's Hospital Medical Center (A.C.M.), School of Medicine, University of Cincinnati, OH; KEMRI-Wellcome Programme (C.R.N.), Kilifi, Kenya and Department of Psychiatry (C.R.N.), University of Oxford, United Kingdom; Division of Epilepsy and Clinical Neurophysiology (A.A.P.), Department of Neurology, Harvard Medical School, Boston Children's Hospital, MA; Harvard Medical School (P.B.P.), Brigham and Women's Hospital, Boston, MA; Department of Internal Medicine and Therapeutics (E.P.), University of Pavia and IRCCS Mondino Foundation, Member of the ERN EpiCARE, Pavia, Italy; UCL Queen Square Institute of Neurology (J.W.S.), London, United Kingdom and Stichting Epilepsie Instelligen Nederland (SEIN) (J.W.S.), Heemstede, Netherlands; University of Melbourne (I.E.S.), Austin and Royal Children's Hospitals, Florey and Murdoch Children's Research Institutes, Melbourne, Australia; Dayanand Medical College (G.S.), Ludhiana, India; Matthew's Friends-Ketogenic Dietary Therapies (E.W.), London, United Kingdom; Department of Paediatric Neurology (J.W.), Red Cross War Memorial Children's Hospital, Neuroscience Institute, Cape Town, South Africa; and UCL NIHR BRC Great Ormond Street Institute of Child Health (J.H.C.), Great Ormond Street Hospital for Children, London, United Kingdom and Member of the ERN EpiCARE (J.H.C.), Young Epilepsy, Lingfield, United Kingdom.

Go to Neurology.org/N for full disclosures. Funding information and disclosures deemed relevant by the authors, if any, are provided at the end of the article.
} 


\section{Glossary}

ACE2 = angiotensin-converting enzyme 2; COVID-19 = coronavirus disease of 2019.

The coronavirus disease of 2019 (COVID-19) pandemic can affect everyone worldwide and cause additional concerns for those with chronic conditions. ${ }^{1}$ An individual's risk of contracting the virus is increased with emergency department visits or hospital admission. People with epilepsy as well as their families/ caregivers and clinicians face further consequences of the pandemic. A coalition of multinational specialists, representing all continents, convened to highlight concerns for people with epilepsy and address safety issues during this period of increased risk and rapid change in access to health care. We seek to provide current information on the possible effect of the COVID-19 pandemic on people with epilepsy, how to keep them safe, given disruptions in clinical services, and provide them with general advice and guidance to find further information. We also provide 2 sets of consensus recommendations, one for health care providers and one for people with epilepsy and their families, addressing best practice in our new reality of epilepsy care. These recommendations are made in the context of COVID-19 and not for use beyond this pandemic. Furthermore, these recommendations should be considered in the context of local circumstances, regulations, and resources.

\section{Methods for consensus statements}

The authors collated questions and concerns from the epilepsy community, predominantly through organizations such as the Epilepsy Foundation and UK Epilepsy Society. A list of statements addressing common questions is formulated and provided and the authors asked to individually score them on a scale of -10 (strongly disagree) to +10 (strongly agree). Five of 11 recommendations for physicians and $3 / 5$ recommendations for individuals/families were rated by all the authors as 7 or above (strongly agree) on the first round of rating. Subsequently, a teleconference was held where statements for which there was a lack of strong consensus were revised until strong consensus was reached.

1. Does SARS-COVID-2 directly cause health issues for persons with epilepsy?

a. Does SARS-COVID-2 precipitate or aggravate existing seizures?

There is limited evidence that the CNS is a target of the SARSCOVID-2 virus. The virus exploits the angiotensinconverting enzyme 2 (ACE2) receptor to enter cells, and CNS glia and neurons express ACE2 receptors, making them potential targets. Other coronavirus infections may cause variable rates of seizures associated with fever or seizure exacerbation (CoV-HKU1 infections $50 \%, \mathrm{HCoV}$ OC43 14\%). ${ }^{2}$ Other coronaviruses are found in the CSF, but the degree to which SARS-COVID-2 penetrates the blood-brain barrier is unclear. ${ }^{3}$ It has been suggested that
SARS-COVID-2 virus may penetrate the brainstem, aggravating respiratory impairment. ${ }^{4}$ Other neurologic manifestations including seizures in severe/end-stage disease likely reflect COVID-19-related hypoxia, encephalopathy, or encephalitis rather than lowered seizure threshold in susceptible individuals with preexistent neurologic disease. Recently, there have also been some reports of neurologic presentations earlier in disease. ${ }^{5}$ Some may include new-onset seizures ${ }^{6}$

b. Are people with epilepsy more predisposed (or vice versa) to COVID-19 infection?

Limited information from countries with experience of the pandemic (e.g., China, Italy, and the United States) suggests that individuals with epilepsy are not more likely to be infected by the virus, nor are they more likely to have severe COVID-19 manifestations because they have epilepsy. Highrisk individuals remain those with diseases restricting mobility, respiratory conditions (including asthma), diabetes mellitus, hypertension, severe heart disease, impaired immune function due to underlying conditions or drug treatment, and older age, particularly when associated with frailty. ${ }^{1}$ People with epilepsy may also have any of these conditions. Because autoimmune disorders are associated with an increased risk of epilepsy and are often treated with immunosuppressive therapies, this is a concern for some people with epilepsy. Individuals with tuberous sclerosis complex, which is often accompanied by epileptic seizures, may have reduced lung function and may also be treated with immune therapy. For certain epilepsy syndromes such as Dravet syndrome, as well as for other epilepsies where seizures are triggered by fever or illness, there may be a risk of worsening in a person with fever due to COVID-19. To date, case reports of worsening have not come forward, which is reassuring. Children are less likely to have severe respiratory illnesses $\left(0.9 \% 0-14\right.$ years $^{7}$ in China, $1.5 \%$ affected were younger than 20 years in Italy $\left.{ }^{8}\right)$.

c. Are there medications that should be avoided in people with epilepsy?

Information is circulating that certain medications, including nonsteroidal anti-inflammatory drugs, such as ibuprofen, should be avoided in the acute phase of infection, although there is no strong evidence to support this recommendation. For people in whom fever control is important (e.g., those with Dravet syndrome), acetaminophen (paracetamol) can be used, followed by ibuprofen as needed. ${ }^{9}$ Some medications used to treat individuals with upper respiratory tract infections, such as the decongestant pseudoephedrine or the antihistamine diphenhydramine, may aggravate seizures in people with epilepsy. ${ }^{10}$

A number of medications are now being studied as possible treatments for COVID-19 to reduce viral load and/or severity of disease. Possible interactions between epilepsy 
medications, antivirals, and other agents that may be used in the management of COVID-19 may need consideration. ${ }^{11}$ Chloroquine and hydroxychloroquine, either alone or with azithromycin, ${ }^{12,13}$ have been discussed. Although rare instances of seizures have been associated with the use of these agents, ${ }^{14,15}$ there are no contraindications in people with epilepsy. ${ }^{16}$ The risk-to-benefit ratio must be assessed in each case if these medications are considered useful.

2. How should we/clinicians modify our clinical care for people with epilepsy during the COVID-19 pandemic?

The pandemic has led to an extraordinary reduction in health care availability. Furthermore, attendance at medical facilities poses an additional risk of contracting the virus for individuals and their carers/families. What is usually regarded as standard practice in case management must now be reconsidered. Clinicians should formulate approaches to reduce emergency department, clinic, and hospital visits to protect people from becoming infected and keep critical resources for those in most urgent need. The pandemic has led to heightened anxiety among clinicians and people with epilepsy, let alone the wider community, highlighting a need for guidance and advice.

Below are the consensus guidance statements for professionals caring for people with epilepsy during the COVID-19 pandemic. These recommendations need to be considered in the context of local resources and circumstances.

a. Try to administer as much care as possible at home to reduce the risk of exposure. Specifically, try to keep people with epilepsy out of areas where they are likely to encounter COVID-19, such as medical offices, outpatient clinics, urgent care facilities, and hospitals.

b. Where possible, people with epilepsy should have an emergency care plan. The threshold to provide emergency rescue medication (e.g., benzodiazepines via buccal, nasal, or rectal routes or oral if they can be safely swallowed) may be lowered. Even a wellcontrolled individual with epilepsy may benefit from having a rescue medication on hand under these unusual circumstances. Individuals with epilepsy and their families/caregivers should have a clear understanding of when and how rescue medications should be used, if they can be repeated, and when emergency department visits are necessary.

c. People with epilepsy and their families/caregivers should be reassured that most tonic-clonic seizures last under 2-3 minutes and do not require emergency medical services or hospital care. Medical/hospital care may be required if tonic-clonic seizures last more than 5 minutes or occur in clusters with no rescue medication available, or if seizures occur in water (baths, swimming), are followed by unusually prolonged postictal symptoms or abnormal recovery, or cause potentially dangerous injury.

d. A regular supply of antiseizure medication should be ensured as well as access to repeat prescriptions and supplies. The importance of taking medication regularly should be emphasized. Stockpiling of medication should be discouraged.

e. At this time, when regular case review and hospital attendance may be hindered, consider whether changes to treatment could be postponed (e.g., weaning medication, changes to vagal nerve stimulator or responsive neurostimulation settings, ketogenic diet changes, or elective epilepsy surgery). Any initiated withdrawal/wean or down-titration of medication should be delayed or reversed unless there are strong reasons for doing otherwise.

f. Key advice on lifestyle issues should be reinforced: the need for regular sleep, consistency in current routines, healthy eating and exercise, and avoidance of recreational drugs and alcohol.

g. Telehealth should be used where possible, using video ideally, or phone if video is not accessible. Such contact with individuals and caregivers/families can alleviate their anxiety and concerns. Follow-up assessments are all possible by telephone or video link.

h. For new presentations, care can be enhanced through careful history taking and home video where possible. ${ }^{17}$ Medical examination and laboratory tests may need to be postponed, unless necessary for short-term management decisions. Many elements of the neurologic examination, from gait assessment to neuro-ophthalmology, can be done using an iPad or similar device.

i. Most individuals with definite or suspected new-onset epilepsy warrant an MRI scan, but during the pandemic, neuroimaging should be postponed unless required to address urgent diagnostic or therapeutic issues. If there is an urgent requirement for imaging, an outpatient facility is preferred and the COVID-19 risk from travel, time in waiting rooms, and exposure to health care workers should be weighed against potential benefits.

j. In most cases, diagnostic EEG can be delayed to a later date. Urgent situations including status epilepticus in the ICU, concern about electrical status epilepticus of slow sleep, nonconvulsive status, or infantile spasms (although video diagnosis of spasms by an experienced pediatric neurologist might be enough to initiate treatment if the risk of hospital attendance outweighs benefit) may require EEG. In some cases (e.g., infantile spasms), a brief outpatient study can provide critical information with low risk if precautions are used.

k. A system to reduce direct exposure of health care professionals to people with epilepsy is advisable. For example, a clinic or hospital service can have a neurologist of the day or a technician performing all EEGs during a certain period and in a single environment. This will facilitate tracking of contacts and minimize disruption should individual health professionals become infected. In managing status epilepticus, additional precautions should be undertaken to prevent airborne spread from secretions. Recommendations are evolving rapidly. Those 
emanating from the ACNS and NAEC can be found below.

1. Mental health issues, particularly depression and anxiety, are common in people with epilepsy regardless of age. Anxiety may particularly be heightened among individuals and their families/ carers from concerns about the pandemic and their epilepsy, as well as from its economic effect. Direction to resources and possible access to helplines should be highlighted. Providers can supply critical reassurance to people with epilepsy and their families.

3. What general advice should we give to people with epilepsy during this crisis?

a. At this time of heightened anxiety, reassurance and basic advice about minimizing the likelihood of seizure exacerbation is key.

b. Consider a comprehensive care plan, with information about what should happen if families/ caregivers are ill or not available.

c. The importance of adherence and maintaining routines should be emphasized. For example, use of pillboxes, cell phone alarms, or phone apps may be helpful, especially if the individual with epilepsy is separated from their usual caregivers/family member, who may be ill and were helping to administer medication.

d. Instructions should be given to maintain a regular medication supply. People with epilepsy and their families/caregivers should work to prevent medication shortages and ensure that repeat prescriptions are available. Consideration should be given to maintain a 3-month supply, where feasible, and trying to obtain medications outside of the hospital setting (e.g., online pharmacies).

e. General advice should be given to ensure adequate sleep where possible and engage in routine exercise, healthy eating, and avoidance of alcohol and recreational drugs, where appropriate. For those with stimulus-induced reflex epilepsies (e.g., photosensitive epilepsy), discussion of reducing or eliminating provocative stimuli (e.g., computer games) may be warranted.

f. Mental health issues, already common among individuals with epilepsy, and families in general, may be exacerbated; reassurance that this is to be expected, with access to telephone advice, may alleviate anxiety.

People with epilepsy may be concerned about whether they are at a higher risk of severe COVID-19 and therefore should entertain stricter quarantine. They should be reassured that in the absence of risk factors, including older age, immobility, coexistent respiratory disease, diabetes mellitus, hypertension, severe heart disease, or immunosuppression, people with epilepsy are not at a higher risk. It is prudent, however, for them to remain isolated from contacts and symptomatic individuals where possible.
4. What are the implications for resource poor countries?

Cases of COVID-19 have been identified in most countries.

The numbers of cases reported from many resourcelimited countries are low at present, but this may reflect a lack of diagnostic facilities and low ascertainment rate. In some countries, a lockdown has been imposed preemptively to contain the spread of infection. Health care systems may be inadequate to deal not only with a massive rise in the number of infected cases but also with the consequences of the lockdown. Telemedicine services might be poorly developed or nonexistent. Medication delivery systems are often nonfunctional, and there may be poor disease and treatment literacy in such settings. Maintaining the supply of antiseizure medication is of great concern. All these pose considerable challenges to epilepsy care providers. Health care professionals are required to make innovative use of available resources to meet these challenges.

The burden of disease overall in resource-limited countries is significant, and the ripple effect of pandemics, such as COVID-19, can disrupt established or evolving health care structures. For example, the Ebola virus outbreak severely affected the capacity to deliver early child intervention programs, including vaccinations. ${ }^{18}$ The result was a wave of inadequately protected children. Similarly, transfer of personnel and resources from obstetric and neonatal services will increase perinatal complications. In Africa, up to a third of epilepsy cases in children may be the result of perinatal insults and a third of adult cases may result from parasitic and other infections. Furthermore, preventive measures will fall away during this pandemic due to lack of resources. Africa has the highest prevalence of HIV infection, significantly increasing the risk of COVID-19 via immunosuppression. Furthermore, the high prevalence of tuberculosis across Africa and Asia adds another layer to the complexity of disease management and risk in these settings. Although most of these individuals do not have epilepsy, they are placed at increased risk and we may see a spike in the number of new cases of epilepsy as a result of the sequelae of the pandemic.

5. Useful information for patients

a. The Epilepsy Foundation, TS Alliance, and the Epilepsy Society UK produced useful information for people with epilepsy, addressing frequently asked questions epilepsy.com/article/2020/3/concerns-about-covid19-coronavirus-and-epilepsy

tsalliance.org/individuals-families/covid-19/

epilepsysociety.org.uk/epilepsy-and-coronaviruscovid-19-faqs\#.Xnp7d252tcg

6. Useful information for physicians

a. Link to updating information on best practices for performing clinical neurophysiology testing (e.g., EEG and ambulatory EEG):

acns.org/practice/covid-19-resources

acns.org/practice/covid-19-resources NAEC 
b. Link to a library of COVID resources from the American Epilepsy Society:

aesnet.org/about_aes/position_statements/covid-19/ home?_cldee $=$ bmF0aGFsaWUuamVOdGVAbXNzbS 51ZHU\%3d\&recipientid $=$ contact $-\mathrm{d} 4343126 \mathrm{~d} 1$ bee 511 98a600155da80a47-b9f22fe613064919b1842dd6ea72 $7 f 96 \&$ esid $=48 \mathrm{c} 95 \mathrm{c} 52-\mathrm{a} 26 \mathrm{e}-\mathrm{ea} 11-8100-000 \mathrm{~d} 3 \mathrm{a} 01 \mathrm{cfd} 3$

c. Resources from the National Association of Epilepsy Centers, including policy updates relevant to epilepsy practices

\section{Study funding}

This consensus statement did not receive any specific grant from funding agencies in the public, commercial, or not-forprofit sectors.

\section{Disclosure}

J.A. French receives NYU salary support from the Epilepsy Foundation and for consulting work and/or attending scientific advisory boards on behalf of the Epilepsy Study Consortium for Acadia, Adamas, Aeonian/Aeovian, Anavex, Arvelle Therapeutics, Inc., Axcella Health, Axovant, Biogen, Biomotiv/Koutif, Blackfynn, Bloom Science, Bridge Valley Ventures, Cavion, Cerebral Therapeutics, Cerevel, Crossject, CuroNZ, Eisai, Empatica, Encoded Therapeutics, Engage Therapeutics, Epitel, Fortress Biotech, GW Pharma, Idorsia, Ionis, Janssen Pharmaceutica, J\&J Pharmaceuticals, Lundbeck, Marinus, NeuCyte, Inc., Neurelis, Neurocrine, Novartis, Otsuka Pharmaceutical Development, Ovid Therapeutics, Inc., Pfizer, Pfizer-Neusentis, Praxis, Redpin, Sage, Shire, SK Life Sciences, Springworks, Stoke, Sunovion, Supernus, Takeda, UCB, Inc., Ultragenyx, West Therapeutic Development, Xenon, Zogenix, and Zynerba; received research grants from Biogen, Cavion, Eisai, Engage, GW Pharma, Lundbeck, Neurelis, Ovid, Pfizer, SK Life Sciences, Sunovion, UCB, Xenon, and Zogenix, as well as grants from the Epilepsy Research Foundation, Epilepsy Study Consortium, and NINDS; is on the editorial board of Lancet Neurology and Neurology Today; is Chief Medical/Innovation Officer for the Epilepsy Foundation for which NYU receives salary support; and has received travel reimbursement related to research, advisory meetings, or presentation of results at scientific meetings from the Epilepsy Study Consortium, the Epilepsy Foundation, Adamas, Arvelle Therapeutics, Inc., Axovant, Biogen, Blackfynn, Cerevel, Crossject, CuroNz, Eisai, Engage, Idorsia, Lundbeck, NeuCyte, Inc., Neurelis, Novartis, Otsuka, Ovid, Pfizer, Redpin, Sage, SK Life Science, Sunovion, Takeda, UCB, Ultragenyx, Xenon, and Zogenix. M.J. Brodie serves on the advisory boards of Xenon and Arvelle Therapeutics and is on the speakers' bureau for Eisai and UCB Pharma. R. Caraballo, O. Devinsky, D. Ding, and L. Jehi report no relevant disclosures. N. Jette receives grant funding paid to her institution for grants unrelated to this work from the NINDS (NIH U24NS107201 and NIH IU54NS100064) and PCORI; receives an honorarium for her work as an Associate Editor of Epilepsia; and is on the editorial board of
Neurology. A. Kanner received honoraria from Eisai Laboratories for chairing a scientific advisory board, from NeuroPace for lectures given in a regional conference, and from the Epilepsy Foundation for services as Co-Editor-in Chief of Epilepsy.com. A.C. Modi receives funding from the NIH (NIDDK and NINR) and PCORI. C.R. Newton and A.A. Patel report no relevant disclosures. P.B. Pennell receives royalties from UpToDate and research support from the NIH (NINDS and NICHD), the Karger Fund, honoraria, and/or travel reimbursements from the AES, AAN, Epilepsy Foundation, and NIH. E. Perucca received speaker or consultancy fees from Amicus Therapeutics, Arvelle, Biogen, Eisai, GW Pharma, Intas Pharmaceuticals, Laboratorios Bagò, Sanofi, Sun Pharma, UCB Pharma, and Xenon Pharma, outside this work. J.W. Sander reports consultancy fees from Eisai, UCB, and Zogenix and grants from Eisai, UCB, and GW Pharma, outside this work; his research is supported by the NIHR University College London Hospitals Biomedical Research Centre, the Dr. Marvin Weil Epilepsy Research Fund, the UK Epilepsy Society, and the Christelijke Vereniging voor de Verpleging van Lijders aan Epilepsie, Netherlands. I.E. Scheffer reports personal fees or speaker honoraria from UCB, Eisai, GlaxoSmithKline, BioMarin, Nutricia, Xenon Pharmaceuticals, Biocodex, and Eisai and receives/has received research support from the National Health and Medical Research Council of Australia, Health Research Council of New Zealand, CURE, Australian Epilepsy Research Fund, March of Dimes, and NIH/NINDS. G. Singh has received funding to organize meetings from several pharmaceutical companies but no personal fees. E. Williams and J. Wilmshurst report no relevant disclosures. J.H. Cross has acted as an investigator for studies with GW Pharma, Zogenix, Vitaflo, and Marinius and has been a speaker and on advisory boards for GW Pharma, Zogenix, and Nutricia; all remuneration has been paid to her department; her research is supported by the National Institute of Health Research (NIHR) Biomedical Research Centre at Great Ormond Street Hospital, NIHR, EPSRC, GOSH Charity, ERUK, and the Waterloo Foundation. Go to Neurology.org/N for full disclosures.

\section{Publication history}

Received by Neurology March 31, 2020. Accepted in final form April 15, 2020.

\section{Appendix Authors}

\begin{tabular}{|c|c|c|}
\hline Name & Location & Contribution \\
\hline $\begin{array}{l}\text { Jacqueline } \\
\text { A. French, } \\
\text { MD }\end{array}$ & $\begin{array}{l}\text { Department of Neurology, } \\
\text { NYU Grossman School of } \\
\text { Medicine New York } \\
\text { University, New York, NY } \\
\text { 10016, USA }\end{array}$ & $\begin{array}{l}\text { Conceptualization of the } \\
\text { manuscript, consensus } \\
\text { vote, initial draft, and } \\
\text { editing }\end{array}$ \\
\hline $\begin{array}{l}\text { Martin J. } \\
\text { Brodie, MD }\end{array}$ & $\begin{array}{l}\text { International Bureau for } \\
\text { Epilepsy, Director, Epilepsy } \\
\text { Unit, Scottish Epilepsy } \\
\text { Initiative, Glasgow, } \\
\text { Scotland }\end{array}$ & $\begin{array}{l}\text { Drafting of the manuscript, } \\
\text { consensus vote, and } \\
\text { editing of the manuscript }\end{array}$ \\
\hline $\begin{array}{l}\text { Roberto } \\
\text { Caraballo, } \\
\text { MD }\end{array}$ & $\begin{array}{l}\text { Hospital J P Garrahan, } \\
\text { Neurology, Buenos Aires, } \\
\text { Argentina }\end{array}$ & $\begin{array}{l}\text { Drafting of the manuscript, } \\
\text { consensus vote, and } \\
\text { editing of the manuscript }\end{array}$ \\
\hline
\end{tabular}


Appendix (continued)

\begin{tabular}{|c|c|c|c|c|c|}
\hline & \\
\hline Name & Location & Contribution & Name & Location & Contribution \\
\hline $\begin{array}{l}\text { Orrin } \\
\text { Devinsky, } \\
\text { MD }\end{array}$ & $\begin{array}{l}\text { Department of Neurology, } \\
\text { NYU Grossman School of } \\
\text { Medicine, New York, NY, } \\
\text { USA }\end{array}$ & $\begin{array}{l}\text { Drafting of the manuscript, } \\
\text { consensus vote, and } \\
\text { editing of the manuscript }\end{array}$ & $\begin{array}{l}\text { Emma } \\
\text { Williams }\end{array}$ & \multirow[t]{2}{*}{$\begin{array}{l}\text { Matthew's } \\
\text { Friends-Ketogenic } \\
\text { Dietary Therapies, } \\
\text { matthewsfriends.org, } \\
\text { London, UK }\end{array}$} & $\begin{array}{l}\text { Drafting of the manuscript, } \\
\text { consensus vote, and } \\
\text { editing of the manuscript }\end{array}$ \\
\hline \multirow{2}{*}{$\begin{array}{l}\text { Ding Ding, } \\
\text { MPH, PhD }\end{array}$} & \multirow{2}{*}{$\begin{array}{l}\text { Institute of Neurology, } \\
\text { Huashan Hospital, Fudan } \\
\text { University, Shanghai, China }\end{array}$} & \multirow{2}{*}{$\begin{array}{l}\text { Drafting of the manuscript, } \\
\text { consensus vote, and } \\
\text { editing of the manuscript }\end{array}$} & & & \\
\hline & & & \multirow[t]{2}{*}{$\begin{array}{l}\text { Jo } \\
\text { Wilmshurst, } \\
\text { MBBS, MD }\end{array}$} & \multirow{2}{*}{$\begin{array}{l}\text { Department of Paediatric } \\
\text { Neurology, Red Cross War } \\
\text { Memorial Children's } \\
\text { Hospital, Neuroscience } \\
\text { Institute, Cape Town, South } \\
\text { Africa }\end{array}$} & \multirow[t]{2}{*}{$\begin{array}{l}\text { Drafting of the manuscript, } \\
\text { consensus vote, and } \\
\text { editing of the manuscript }\end{array}$} \\
\hline $\begin{array}{l}\text { Lara Jehi, } \\
\text { MD }\end{array}$ & $\begin{array}{l}\text { Cleveland Clinic Epilepsy } \\
\text { Center, Cleveland, OH, USA }\end{array}$ & $\begin{array}{l}\text { Drafting of the manuscript, } \\
\text { consensus vote, and } \\
\text { editing of the manuscript }\end{array}$ & & & \\
\hline $\begin{array}{l}\text { Nathalie } \\
\text { Jette, MSc, } \\
\text { MD }\end{array}$ & $\begin{array}{l}\text { Icahn School of Medicine at } \\
\text { Mount Sinai, Department } \\
\text { of Neurology, New York, } \\
\text { NY, 10029, USA }\end{array}$ & $\begin{array}{l}\text { Drafting of the manuscript, } \\
\text { consensus vote, and } \\
\text { editing of the manuscript }\end{array}$ & \multirow[t]{2}{*}{$\begin{array}{l}\text { J. Helen } \\
\text { Cross, } \\
\text { MBChB, PhD }\end{array}$} & \multirow{2}{*}{$\begin{array}{l}\text { UCL NIHR BRC Great } \\
\text { Ormond Street Institute of } \\
\text { Child Health, Great } \\
\text { Ormond Street Hospital for } \\
\text { Children, London WC1N } 1 \\
\text { EH \& Young Epilepsy, } \\
\text { Lingfield, Member of the } \\
\text { ERN EpiCARE, UK }\end{array}$} & \multirow[t]{2}{*}{$\begin{array}{l}\text { Conceptualization of the } \\
\text { manuscript, consensus } \\
\text { vote, initial draft, and } \\
\text { editing }\end{array}$} \\
\hline $\begin{array}{l}\text { Andres } \\
\text { Kanner, MD }\end{array}$ & $\begin{array}{l}\text { Division of Epilepsy, } \\
\text { Department of Neurology, } \\
\text { University of Miami, Miller } \\
\text { School of Medicine Miami }\end{array}$ & $\begin{array}{l}\text { Drafting of the manuscript, } \\
\text { consensus vote, and } \\
\text { editing of the manuscript }\end{array}$ & & & \\
\hline
\end{tabular}

Appendix (continued)

\begin{tabular}{lll}
\hline Avani C. & Cincinnati Children's & $\begin{array}{l}\text { Drafting of the manuscript, } \\
\text { consensus vote, and } \\
\text { Modi, PhD }\end{array}$ \\
& $\begin{array}{l}\text { Hospital Medical Center, } \\
\text { University of Cincinnati- } \\
\text { School of Medicine, } \\
\text { Cincinnati, OH, 45229 USA }\end{array}$ & \\
&
\end{tabular}

\begin{tabular}{lll}
\hline Charles R. & KEMRI-Wellcome & $\begin{array}{l}\text { Drafting of the manuscript, } \\
\text { consensus vote, and } \\
\text { Newton, }\end{array}$ \\
MD, FRCP & $\begin{array}{l}\text { Programme, Kilifi, Kenya } \\
\text { and Department of } \\
\text { Psychiatry, University of }\end{array}$ & editing of the manuscript \\
& Oxford, Oxford, UK
\end{tabular}

\begin{tabular}{lll}
\hline $\begin{array}{l}\text { Archana A. } \\
\text { Patel, MD, }\end{array}$ & $\begin{array}{l}\text { Boston Children's Hospital, } \\
\text { Harvard Medical School }\end{array}$ & $\begin{array}{l}\text { Drafting of the manuscript, } \\
\text { consensus vote, and } \\
\text { MPH }\end{array}$ \\
$\begin{array}{ll}\text { Department of Neurology, } \\
\text { Division of Epilepsy \& }\end{array}$ & \\
& Clinical Neurophysiology, \\
& Boston, MA, USA
\end{tabular}

\begin{tabular}{|c|c|c|}
\hline $\begin{array}{l}\text { Page B. } \\
\text { Pennell, MD }\end{array}$ & $\begin{array}{l}\text { Harvard Medical School, } \\
\text { Brigham and Women's } \\
\text { Hospital, Boston, MA, USA }\end{array}$ & $\begin{array}{l}\text { Drafting of the manuscript, } \\
\text { consensus vote, and } \\
\text { editing of the manuscript }\end{array}$ \\
\hline $\begin{array}{l}\text { Emilio } \\
\text { Perucca, } \\
\text { MD, PhD }\end{array}$ & $\begin{array}{l}\text { Department of Internal } \\
\text { Medicine and } \\
\text { Therapeutics, University of } \\
\text { Pavia and IRCCS Mondino } \\
\text { Foundation, Member of } \\
\text { the ERN EpiCARE, Pavia, } \\
\text { Italy }\end{array}$ & $\begin{array}{l}\text { Drafting of the manuscript, } \\
\text { consensus vote, and } \\
\text { editing of the manuscript }\end{array}$ \\
\hline $\begin{array}{l}\text { Josemir W. } \\
\text { Sander, MD, } \\
\text { PhD, FRCP }\end{array}$ & $\begin{array}{l}\text { UCL Queen Square } \\
\text { Institute of Neurology, } \\
\text { London WC1N 3BG, UK \& } \\
\text { Stichting Epilepsie } \\
\text { Instelligen Nederland } \\
\text { (SEIN), Heemstede, } \\
\text { Netherlands }\end{array}$ & $\begin{array}{l}\text { Drafting of the manuscript, } \\
\text { consensus vote, and } \\
\text { editing of the manuscript }\end{array}$ \\
\hline
\end{tabular}

\begin{tabular}{lll}
\hline $\begin{array}{l}\text { Ingrid E. } \\
\text { Scheffer, } \\
\text { MBBS, PhD }\end{array}$ & $\begin{array}{l}\text { University of Melbourne, } \\
\text { Austin and Royal Children's } \\
\text { Hospitals, Florey and } \\
\text { Murdoch Children's } \\
\text { Research Institutes, } \\
\text { Melbourne, Australia }\end{array}$ & $\begin{array}{l}\text { Drafting of the manuscript, } \\
\text { consensus vote, and } \\
\text { editing of the manuscript }\end{array}$ \\
\hline $\begin{array}{l}\text { Gagandeep } \\
\text { Singh, MD }\end{array}$ & $\begin{array}{l}\text { Dayanand Medical College, } \\
\text { Ludhiana, India }\end{array}$ & $\begin{array}{l}\text { Drafting of the manuscript, } \\
\text { consensus vote, and } \\
\text { editing of the manuscript }\end{array}$ \\
\hline
\end{tabular}

\section{References}

1. Preliminary estimates of the prevalence of selected underlying health conditions among patients with coronavirus disease 2019-United States, February 12-March 28, 2020. MMWR Morb Mortal Wkly Rep 2020;69:382-386.

2. Lau SKP, Woo PCY, Yip CCY, et al. Coronavirus HKU1 and other coronavirus infections in Hong Kong. J Clin Microbiol 2006;44:2063-2071.

3. Baig AM,Khaleeq A, Ali U, Syeda H. Evidence of the COVID-19 virus targeting the CNS: tissue distribution, Host-Virus interaction, and proposed neurotropic mechanisms. ACS Chem Neurosci 2020;11:995-998.

4. Li YC, Bai WZ, Hashikawa T. Tsutomu Hashikawa the neuroinvasive potential of SARS-CoV2 may play a role in the respiratory failure of COVID-19 patients. J Med Virol 2020:1-4.

5. Nath A. Neurologic complications of coronavirus infections. Neurology 2020 Epub 2020 Mar 30. doi: 10.1212/WNL.0000000000009455.

6. Available at: journals.lww.com/neurotodayonline/blog/breakingnews/pages/post. aspx?PostID=920.

7. Guan WJ, Ni ZY, Hu Y, et al. Clinical characteristics of coronavirus disease 2019 in China [published online ahead of print, 2020 Feb 28]. N Engl J Med 2020. doi: 10.1056/NEJMoa2002032.

8. Sorbello M, El-Boghdadly K, Di Giacinto I, et al. The Italian COVID-19 Outbreak: experiences and recommendations from clinical practice. Anaesthesia 2020 Epub Mar 2020. doi: 10.1111 /anae.15049.

9. Sodhi M, Etminan M. Safety of ibuprofen in patients with COVID-19: causal or confounded? Chest 2020 Epub. doi: 10.1016/j.chest.2020.03.040.

10. Olson KR, Kearney TE, Dyer JE, Benowitz NL, Blanc PD. Seizures associated with poisoning and drug overdose. Am J Emerg Med 1994;12:392-395.

11. Russo E, Iannone L. Clinically relevant Drug-Drug interaction between AEDs and medications used in the treatment of COVID-19 patients. Available at: ilae.org/files/ dmfile/Antiepileptic-drugs-interactions_in_COVID-19.pdf. Accessed March 26, 2020 .

12. Colson P, Rolain JM, Raoult D. Chloroquine for the 2019 novel coronavirusSARS-CoV2. Int J Antimicrob Agents 2020. doi: 10.1016/j.jantimicag.2020.105923.105923.

13. Gautret P, Lagier JC, Parola P, et al. Hydroxychloroquine and azithromycin as a treatment of COVID-19: results of an open-label non-randomized clinical trial. Int J Antimicrob Agents. doi: 10.1016/j.ijantimicag.2020.105949.

14. Avoclor Tablets, Summary of Product Characteristics. Available at: medicines.org.uk/ emc/product/5490/smpc. Accessed March 26, 2020.

15. Malcangi G, Fraticelli P, Palmieri C, Cappelli M, Danieli MG. Hydroxychloroquineinduced seizure in a patient with systemic lupus erythematosus. Rheumatol Int 2000; 20:31-33.

16. Plaquenil-hydroxychloroquine Sulfate. Summary of Product Characteristics. Available at: medicines.org.uk/emc/product/1764/smpc. Accessed March 26, 2020.

17. Ojeda J. Utility of home-made videos in an adult epilepsy clinic. J Neurol Disord 2016; 4:311.

18. Sun X, Samba TT, Yao J, et al. Impact of the Ebola outbreak on routine immunization in western area, Sierra Leone-a field survey from an Ebola epidemic area. BMC Public Health 2017;17:363. 


\section{Neurology}

\section{Keeping people with epilepsy safe during the COVID-19 pandemic \\ Jacqueline A. French, Martin J. Brodie, Roberto Caraballo, et al. \\ Neurology 2020;94;1032-1037 Published Online before print April 23, 2020 \\ DOI 10.1212/WNL.0000000000009632}

This information is current as of April 23, 2020

Updated Information \&

Services

References

Citations

Subspecialty Collections

Permissions \& Licensing

Reprints including high resolution figures, can be found at: http://n.neurology.org/content/94/23/1032.full

This article cites 13 articles, 2 of which you can access for free at: http://n.neurology.org/content/94/23/1032.full\#ref-list-1

This article has been cited by 5 HighWire-hosted articles: http://n.neurology.org/content/94/23/1032.full\#\#otherarticles

This article, along with others on similar topics, appears in the following collection(s):

All Epilepsy/Seizures

http://n.neurology.org/cgi/collection/all_epilepsy_seizures

Viral infections

http://n.neurology.org/cgi/collection/viral_infections

Information about reproducing this article in parts (figures,tables) or in its entirety can be found online at:

http://www.neurology.org/about/about_the_journal\#permissions

Information about ordering reprints can be found online:

http://n.neurology.org/subscribers/advertise

Neurology ${ }^{\circledR}$ is the official journal of the American Academy of Neurology. Published continuously since 1951, it is now a weekly with 48 issues per year. Copyright @ 2020 American Academy of Neurology. All rights reserved. Print ISSN: 0028-3878. Online ISSN: 1526-632X.

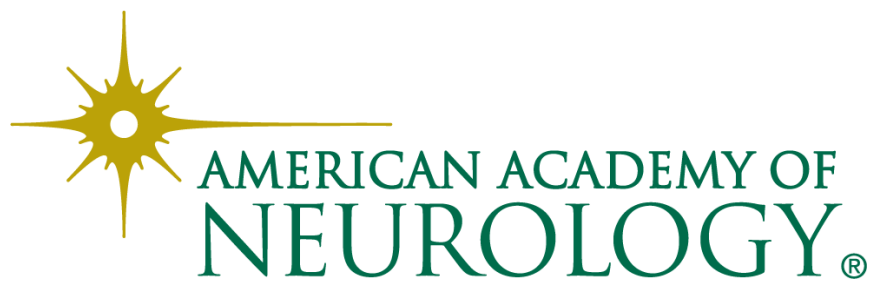

